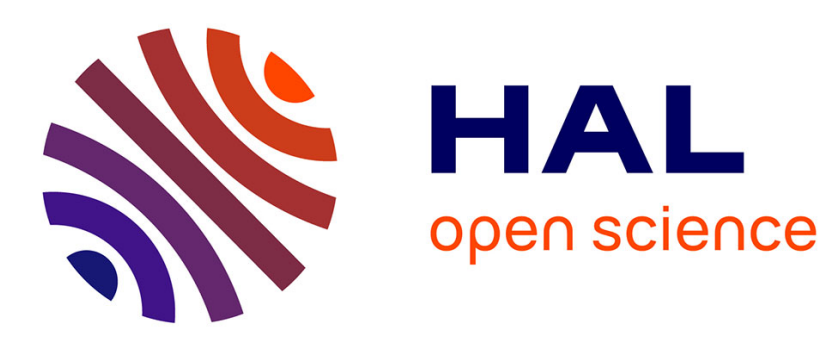

\title{
Shades of the Innovation-Purchasing function - the missing link of Open Innovation
}

Romaric Servajean-Hilst, Richard Calvi

\section{To cite this version:}

Romaric Servajean-Hilst, Richard Calvi. Shades of the Innovation-Purchasing function - the missing link of Open Innovation. International Journal of Innovation Management, In press, 22 (1). hal01700648

\section{HAL Id: hal-01700648 \\ https://hal.univ-smb.fr/hal-01700648}

Submitted on 5 Feb 2018

HAL is a multi-disciplinary open access archive for the deposit and dissemination of scientific research documents, whether they are published or not. The documents may come from teaching and research institutions in France or abroad, or from public or private research centers.
L'archive ouverte pluridisciplinaire HAL, est destinée au dépôt et à la diffusion de documents scientifiques de niveau recherche, publiés ou non, émanant des établissements d'enseignement et de recherche français ou étrangers, des laboratoires publics ou privés. 


\title{
Shades of the Innovation-Purchasing function - the missing link of Open
}

\section{Innovation}

Romaric SERVAJEAN-HILST, i3-CRG laboratory, Ecole polytechnique - CNRS -

Université Paris Saclay -828, boulevard des Maréchaux - 91762 Palaiseau, France romaric.servajean-hilst@polytechnique.edu

\author{
Richard CALVI, IREGE laboratory, Université Savoie Mont Blanc, \\ 2, route de Saint-Cassin, IAE SMB, Bat 23, 73011 CHAMBERY, France \\ Richard.calvi@univ-savoie.fr
}

\section{Purpose}

This paper seeks to instigate a new area of research in the EPI (Early Purchasing Involvement) literature around the question: How should a purchasing function evolve in order to identify and capture innovation in the supplier market? Particularly, we attempt to characterize the specificities of the Innovation-Purchasing functions, an emerging function acting in the fuzzy-front-end of projects. The contribution of this paper is a reification of the role of an Innovation-Purchasing function in an Open Innovation context, through the description of Early Purchasing Involvement in the Innovation $\left(\mathrm{EPI}^{2}\right)$ agenda.

\section{Design/methodology/approach}

In this empirical paper, the data is collected through an internal benchmarking study within a multinational multidivisional firm evolving in the automotive sector where a Purchasing function dedicated to Innovation is established in its various divisions. It is then analysed using the framework developed by Van Echtelt et al. (2008) to specify which activities are necessary to manage Early Supplier Involvement (ESI).

\section{Findings}

Our study reveals similarities and differences between the observed practices of what we call Early Purchasing Involvement in Innovation $\left(\mathrm{EPI}^{2}\right)$ and the more classical EPI activities in an NPD context. Specifically, we observed an enforced strategic role of $\mathrm{EPI}^{2}$ that influences the innovation process by aligning it to supplier market capabilities and purchasing strategies. 


\section{Research limitations/implications}

The research is based on a specific case study in the automotive sector. Further studies could consider some other contexts or test the applicability of the findings to other industries.

\section{Practical implications}

The implications of the purchasing function is an emerging topic of interest in a lot of industries. The insights developed in this paper help such firms recognise the specific issues and contents to support $\mathrm{EPI}^{2}$ through some organisational decisions.

\section{Originality/value}

As an in-depth study of a single company dealing with an emerging topic, this research responds to calls for studies embedded in reality.

Key words: Early Purchasing Involvement, Open Innovation, Organisation of purchasing function.

\section{Introduction}

During the last decade, firms have been multiplying their collaborative innovation programs to respond to both the acceleration of innovation and the increase in resource scarcity. Based on Chesbrough's best seller (Chesbrough, 2003), Open Innovation has become a widely spread motto for the phenomenon where firms' innovative resources and capabilities go beyond their boundaries. In order to get efficient use of such resources and capabilities, firms are now looking for the best ways to organize themselves and interact with other firms (Kang \& Kang, 2009; Lawson \& Samson, 2001; Lazzarotti \& Manzini, 2009) - more specifically with their innovative suppliers. This latter subject has been investigated for over 25 years by a plethora of research concerning Early Supplier Involvement (ESI) in New Product Development (NPD) (e.g. Cousins et al., 2006; T. E. Johnsen, 2009; Petersen, Handfield, \& Ragatz, 2005; Van Echtelt, Wynstra, Van Weele, \& Duysters, 2008). Actually, this body of 
research has demonstrated that suppliers are critical sources of innovation and that collaborating with suppliers as part of the NPD process enables innovating companies to capitalize on suppliers' complementary capabilities, thereby improving innovation and NPD performance (Brem \& Tidd, 2012).

In such relationships, the quality of the interaction is an important driver for generating learning and value creation (Gardet \& Mothe, 2011; Kang \& Kang, 2009; Parmigiani \& Mitchell, 2010). Within the various organizational functions that interact with suppliers as part of NPD projects, Purchasing performs as an important go-between function in order to facilitate ESI processes (Eslami \& Lakemond, 2015; Lakemond, Echtelt, \& Wynstra, 2001; Luzzini, Amann, Caniato, Essig, \& Ronchi, 2015; Wynstra, Axelsson, \& Weele, 2000). However, although more than 30 years have passed since Farmer (1981) argued the need for Purchasing to be involved in NPD, relatively little progress has been made in research on this challenge. In fact, despite the upsurge of research on ESI, most of the literature overlooks the role of Purchasing in this process (EPI), suggesting little interest, for example, in the role of the Purchasing organizational structure on NPD performance (Schiele, 2010). As the EPI literature is intimately linked to the ESI literature, its focus relies mainly on Purchasing involvement in NPD rather than in fuzzy-front-ends of projects, where the innovation is not yet formally defined.

Now, the stakes and logics related to fuzzy-front-end innovation are traditionally managed separately from those related to new product development: there are different roles and activities completed through different interacting functions (Maniak \& Midler, 2008). For these authors, in a co-development process, the buying function must deal mainly with wellknown suppliers in the project time-scheduling and with a clear vision of the shared responsibilities between client and partner. When a company seeks to introduce co- 
innovation, the buying function must investigate, often outside the traditional supplier base, and on a fuzzy idea of value added for the firm's offer creation process (Phillips, Lamming, Bessant, \& Noke, 2006). For Maniak and Midler, it is obvious that, to manage vertical coinnovation properly, the company must define a new EPI process to perform this role. In this article we name this set of activities “Early Purchasing Involvement in Innovation” $\left(\mathrm{EPI}^{2}\right)$.

This way, our research question is the following: When a company decides to structure an Innovation-Purchasing function, how does the role of the actor in charge of this function evolve from the more traditional EPI in NPD? To investigate this evolution, we conducted an exploratory research based on an in-depth case study where we collected data through an internal benchmark within a multinational/multidivisional firm that had implemented a Purchasing function, specifically dedicated to innovation projects.

\section{Literature review}

\subsection{Purchasing Involvement in NPD literature}

For researchers in EPI, Purchasing entities are acknowledged as the most relevant for the management of the selecting process of the suppliers to be integrated into a New Product Development (NPD) project (T. E. Johnsen, 2009; Petersen et al., 2005; Van Echtelt et al., 2008). Indeed, Purchasing is considered as the most appropriate function likely to measure the availability and relevance of external resources for integration into the NPD process of the firm (Schiele, 2006; Wynstra, van Weele, \& Axelsson, 1999). Their knowledge of the competition in the market enables them to recognize the value of knowledge therein and facilitate their business’s access to them and their acquisition (Trent \& Monczka, 1998).

In addition, the Purchasing function not only contributes to NPD performance through its 
action on cost, quality and time issues. It also contributes to innovation, by linking innovation strategies and external resources management during NPD projects (Gonzalez-Zapatero, Gonzalez-Benito, \& Lannelongue, 2016; Melander \& Lakemond, 2014; Van Echtelt et al., 2008). It contributes to the future success of new products, when their innovativeness is connected not only to the Research \& Development department but also to other functions, such as manufacturing, quality or marketing (D’Antone \& Santos, 2016; Eslami \& Lakemond, 2015). In that context, Purchasing proves to be key to achieve satisfactory integration between R\&D and manufacturing (Olausson, Magnusson, \& Lakemond, 2009). Besides, when it is also connected to Marketing, it contributes to NPD consistency along the supply chain, from specifications to commercialisation phases (Gonzalez-Zapatero et al., 2016).

Furthermore, as a key-manager of the relationship with suppliers, Purchasing contributes to its firm's NPD through the consolidation and growth of supplier involvement. By defining the business atmosphere of the supplier-buyer relationship, Purchasing can influence its suppliers' willingness to invest, or not, in their client' innovative efforts (Pulles, Veldman, \& Schiele, 2014; Smals \& Smits, 2012). Through in-house information about a supplier's state and strategy, it can also limit the risks of inconsistencies, which would lead to the supplier's disengagement (Smals \& Smits, 2012). Through these pivotal roles, it can contribute, first, to successful supplier integration (Wynstra et al., 1999; Wynstra, Weggeman, \& Van Weele, 2003); second, to supplier's satisfaction, resulting in the client firm becoming a "customer of choice" the supplier first presents its innovative ideas and products to (Luzzini et al., 2015; Schiele, 2012).

In this literature, it is also pointed out there may be a distinction in Purchasing departments between entities in charge of the "life-cycle" (or "strategy") sourcing and "advanced" (or 
“forward”) sourcing (T. Johnsen, Calvi, \& Phillips, 2011; Schiele, 2010). This distinction relies on the application of the exploration-exploitation dilemma shaping described by (March, 1991): the stakes and logics related to exploitation activities are traditionally managed separately from those related to exploration activities and hardly compatible. One answer to this dilemma is the organizational ambidexterity of the Purchasing department (Blome, Schoenherr, \& Kaesser, 2013; Jurksiene \& Pundziene, 2016) with such a distinction, where Life-cycle Purchasing is in charge of strategic sourcing and Advanced Purchasing in charge of sourcing for NPD.

The former entity has stronger supply-chain and quality-cost-delivery orientation (and a stronger link with internal customers) than the latter, which focuses on new product development projects (T. Johnsen et al., 2011; Schiele, 2010). Meanwhile, the latter entity supports (a) sourcing activities for a given project, (b) selects the necessary technologies and (c) participates in the same project (Melander \& Lakemond, 2014; Wynstra et al., 2003). In some cases, that role of "advanced buyer" can be split into two separate entities, as occurs in the fuzzy-front-end of innovation or as part of an NPD project (T. Johnsen et al., 2011; Schiele, 2010). This need for specific organizations and activities to manage fuzzy-front-end vs. latter stages of development is well known in NPD literature (Brentani \& Reid, 2012; Maniak \& Midler, 2008). It is also identified in EPI literature (Ben Mahmoud-Jouini \& Charue-Duboc, 2014; T. E. Johnsen \& Mikkelsen, 2015; Luzzini \& Ronchi, 2010; Rehm, Schupp, \& Matthyssens, 2015), where a distinction might be found between explorative and exploitative innovation (Blome et al., 2013). However, as New Product Development proves to be quite the only context in which the literature considers purchasers' contributions to innovation (D'Antone \& Santos, 2016), $\mathrm{EPI}^{2}$ is still poorly documented, operationally speaking. 


\subsection{Purchasing involvement in Open Innovation literature,}

Since the seminal book presenting the paradigm of Open Innovation (Chesbrough, 2003), this field of study has tremendously grown and evolved in multiple directions (Chesbrough, Vanhaverbeke, \& West, 2014). Within the literature that studies how organizations purposely manage knowledge flows beyond their boundaries, in line with their business models (ibid), networks management of interrelated firms is considered as a key determinant for firms' capacity to innovate with success (Chesbrough, 2003; Chesbrough et al., 2014). Nevertheless, client-supplier collaboration on innovation is given little attention.

Scouting and acquisition of external knowledge for a focal organization, such as Intellectual property assets or technology, are considered as Open Innovation practices (Dahlander \& Gann, 2010; Gassmann \& Enkel, 2004; Kang \& Kang, 2009), as they consist in key steps for firms’ absorptive capacity (Cohen \& Levinthal, 1990). Nevertheless, the involvement of Purchasing entities in such steps receives little attention (Servajean-Hilst, 2014). Furthermore, if cross-functional integration is recognized as important for successful Open Innovation (West \& Bogers, 2014), the studied functions are mainly Marketing and Research \& Development.

Out of the research work done by EPI academics publishing in Open Innovation field (e.g. Melander \& Lakemond, 2015; Schiele, 2010), the involvement of Purchasing entities in Open Innovation activities is barely studied. To our knowledge, and based on research on ebscohost and google scholar (with the term “Open Innovation” AND“Purchas*” OR "Procurement” OR "buy*"), there are only two examples of articles on Purchasing involvement in Open Innovation where the Purchasing function is explicitly included. The first is given by the unique case of a firm where Open Innovation was jointly and spontaneously implemented by the R\&D and Procurement functions, without the support of top management (Mortara \& 
Minshall, 2011). In the second example, the function is dubbed counterproductive for Open Innovation: "If you rely on your purchasing organization for buying your external $R \& D$, you're setting yourself up for a terrible, terrible fall” (Chesbrough \& Euchner, 2011). Nevertheless, the necessity for Open Innovation scholars to study new functional areas was recently raised, and "Procurement” specifically named (Vanhaverbeke, West, \& Chesbrough, 2014). However, the new role of Purchasing identified in ESI literature is still to be considered in Open Innovation context, which is beyond the New Product Development context.

\subsection{An analysis grid for ESI2}

An activity-based framework was developed and adjusted by (Van Echtelt \& Wynstra, 2001; Van Echtelt et al., 2008; Wynstra et al., 1999, 2003), to describe the practices for managing supplier involvement in new product development. The original assumption was that there was a need for opening the focus of ESI studies, from the context of single development projects to an extended focus on longer-terms activities, such as client-supplier relationship management or internal technology strategy (Wynstra et al., 1999). In the same line of thought, (Lakemond et al., 2001) proposed a typology for involving purchasing in NPD, based on the degree of coordination and the level of purchaser integration, whose purpose was to identify the best degree of involvement in a specific project. Wynstra et al. (2003) identified the activities with a focus on the integration of purchasing and product development processes, identifying four levels of management: (1) development management of the client firm, (2) supplier interface management, (3) project management, and (4) product management. 
The first set of managerial processes, development management, consists in establishing the rules for ESI in NPD and the technological areas to collaborate in; the second, supplier interface management, focuses on establishing a supplier base that can be involved in the client's NPD; the third, project management, focuses on planning and on the implementation of suppliers in a specific NPD project; the final one, product management, refers to the design or specifications of the new product rather than to the project (Van Echtelt et al., 2008, p. 184). These frameworks were ultimately revised by (Van Echtelt et al., 2008), who proposed a classification that underlines the intertwining of strategic and operational project management activities. The studies cited above focused on the activities related to New Product Development and offered a grid for identifying the variety of purchasing activities in that context (Table 1). Thus, this grid will serve as a basis framework to answer our research question.

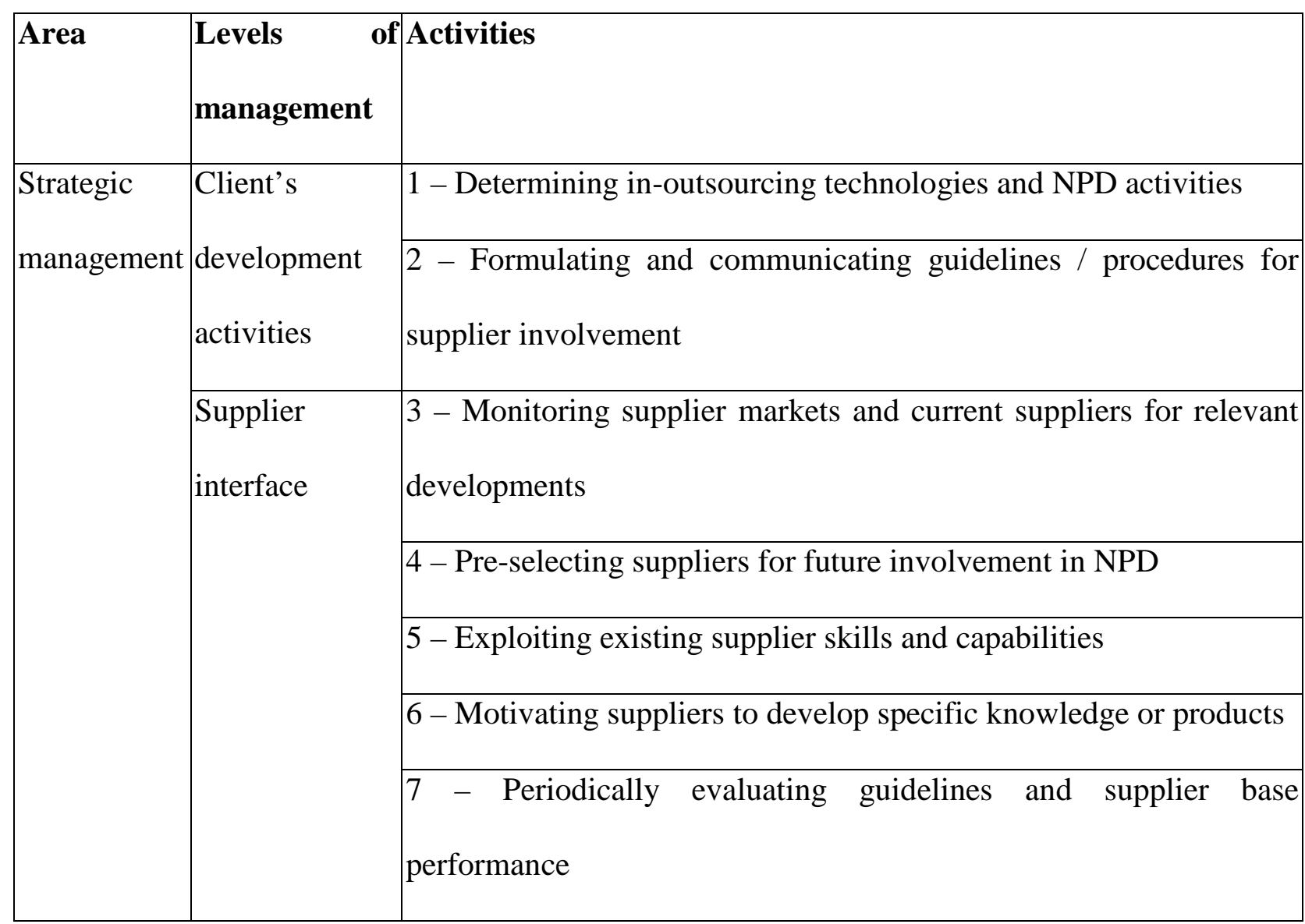




\begin{tabular}{|c|c|c|}
\hline Operational & Project & 8 - Determining project specific develop-or-buy solutions \\
\hline project & Product & 9 - Suggesting alternative technologies components, suppliers \\
\hline management & Project & 10 - Selecting suppliers for involvement in development project \\
\hline & & 11 - Determining the extent and moment of supplier involvement \\
\hline & & 12 - Determining operational targets and work-package \\
\hline & & 13 - Designing communication interface with suppliers \\
\hline & & 14 - Coordinating development activities with suppliers \\
\hline & Product & 15 - Evaluating part designs \\
\hline & $\begin{array}{l}\text { Supplier } \\
\text { interface }\end{array}$ & 16 - Evaluating / feedback on supplier performance \\
\hline
\end{tabular}

Table 1: Management processes for Managing Supplier Involvement in New Product Development (adapted from Wynstra et al., 2003; Van Echtelt et al., 2008)

\section{Methodology}

As our research question is explorative, we decided to adopt an in-depth case-based research method (Meredith, 1998). The empirical research is based on an internal benchmark of the Purchasing functions within a multinational/multidivisional firm, AUTO group (a pseudonym), that are specifically dedicated to innovation projects. The objective of this benchmark was to "share practices implemented in each division and non-production purchasing, and define recommendations or best practices to improve AUTO’s InnovationPurchasing organizations"1. This case was selected for its capacity to bring "in-depth understandings and insights” (Dubois \& Araujo, 2007, p. 179; Yin, 2009) of an emerging function: the studied entities have been created in three of the divisions for more than 3 years

\footnotetext{
${ }^{1}$ Mission given by the Purchasing Vice-Presidents of the 4 Divisions of AUTO group to carry out this internal benchmark
} 
(8 years regarding one division), which allows the installation, and observation, of internal routines.

The benchmark was conducted during the year 2014 with these entities' managers and top managers, supported with one of the authors' implication, through 4 workshops (1 to 5 hours each) where actors' means, roles and missions in this function were presented and debated. A synthesis was jointly realized, under the direction of the present author, and shared with the Purchasing Vice-Presidents of the AUTO group. The workshops were fully transcribed by the participating-researcher (11,000 words); the slideshows presented and specially written for the benchmark were collected and anonymized. This internal benchmark was the first joint activities of the four Innovation-Purchasing entities of AUTO group.

The coding process was a manual bottom-up process, assigning codes to the interviews and elements of the slideshows. As the primary objective of this study was to identify the specificities of Purchasing entities dedicated to innovation, we first screened our data to recognize the activities performed by such a function. For each of the four divisions Purchasing functions involved in the innovation process, these activities were coded and categorized into themes (Miles, Huberman, \& Saldana, 2014), using the framework of (Van Echtelt et al., 2008). The second step was to import the raw verbatim into a scheme linked to each class of activities found in the initial model presented in Table 1 . This part of the analysis was conducted by one of the authors. Hereafter, activities were categorized and consolidated into meaningful themes through a dialogue between the authors. It led us to identify the activities already identified for the management of NPD involving suppliers. It also led us to identify the activities not described by such framework, but could be classified using the levels of management described by earlier framework from (Wynstra et al., 2003). Second, we were able to identify and analyse the specificities of Purchasing's involvement in 
the firm's innovation, $\mathrm{EPI}^{2}$, regarding its involvement in NPD. Finally, we extracted the verbatim that best illustrates the activities framed by this work.

\section{The Case study and findings}

\subsection{Research settings}

AUTO group is a leading tier-one supplier in the automotive sector, with four main divisions that produce different parts of the car: Division A, Division B, Division C and Division D. For confidentiality reasons, the specificities of the products made by each division cannot be disclosed. Table 2 presents some characteristics.

\begin{tabular}{|c|c|c|c|c|}
\hline & Division A & Division B & Division C & Division D \\
\hline Products & $\begin{array}{l}\text { Systems for the } \\
\text { cockpit }\end{array}$ & $\begin{array}{c}\text { Systems and } \\
\text { subsystems for the } \\
\text { cockpit }\end{array}$ & $\begin{array}{c}\text { Power train } \\
\text { subsystem }\end{array}$ & $\begin{array}{l}\text { Passive security } \\
\text { systems }\end{array}$ \\
\hline $\begin{array}{l}\text { Relative technical } \\
\text { complexity of } \\
\text { products }\end{array}$ & + & ++ & + & - \\
\hline $\begin{array}{c}\text { Annual Turn- } \\
\text { Over }\end{array}$ & $€ 4,500 \mathrm{~m}$ & $€ 5,500 \mathrm{~m}$ & $€ 6,500 \mathrm{~m}$ & $€ 2,000 \mathrm{~m}$ \\
\hline $\begin{array}{c}\text { Number of } R \& D \\
\text { people }\end{array}$ & 1160 & 1420 & 850 & 319 \\
\hline $\begin{array}{l}\text { Number of } \\
\text { Purchasing } \\
\text { people }\end{array}$ & 420 & 360 & 280 & 100 \\
\hline
\end{tabular}

Table 2: key figures of AUTO group divisions

In the entire group, central guidelines underline the strategic importance of the supplier and of innovation. Innovation is supported in each division by a Research \& Development department, where Research activities are conducted by laboratories - each in charge of their own area of scientific expertise. Innovation projects are led by Innovation project managers 
in $\mathrm{R} \& \mathrm{D}$ and produce off-the-shelf innovative products and processes: the concept has been defined and tested and verified. Each division follows a similar stage-gate process for managing innovation projects (figure 1), from fuzzy-front-end to transfer to development: the monthly innovation committees. Development activities are engaged when an innovative product is subscribed by a car manufacturer for a specific car or platform: a new program is launched. Development ends when the product goes into production.
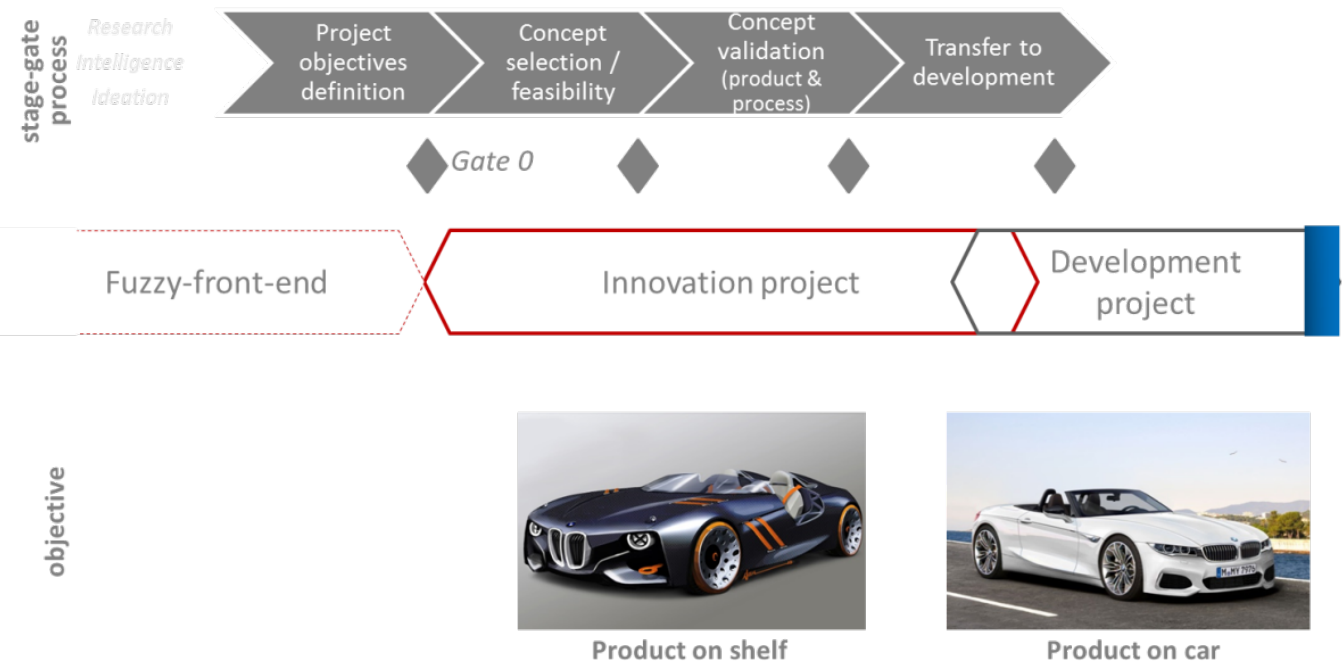

Figure 1: Stage gates of innovation project management at AUTO group

Each division has its own and dedicated Purchasing Direction. A central Purchasing Direction is dedicated to non-production purchasing but has no team dedicated to innovation. Each Purchasing Direction division has five major types of Purchasing functions: (1) Program Purchasing and Serial Life Purchasing, (2) Commodity Purchasing, (3) Tools and Capital expenses Purchasing, (4) Supplier Quality and (5) Innovation or Advanced Purchasing. No common processes of Purchasing or Innovation are common to the various divisions, but every Innovation or Advanced Purchasing entity is represented in monthly innovation committees and physically located in R\&D centres. An overview of the attributes of the Innovation-Purchasing entities in each division is presented in Table 3. These entities 
represent the advanced-buyer described in EPI literature, which we proposed to designate as $\mathrm{EPI}^{2}$. In Division A, B and D, they are more dedicated to the fuzzy-front-end of innovation. In Division C, they are more dedicated to the innovation project as defined in AUTO group (cf. Figure 1), when the first stage gate is passed.

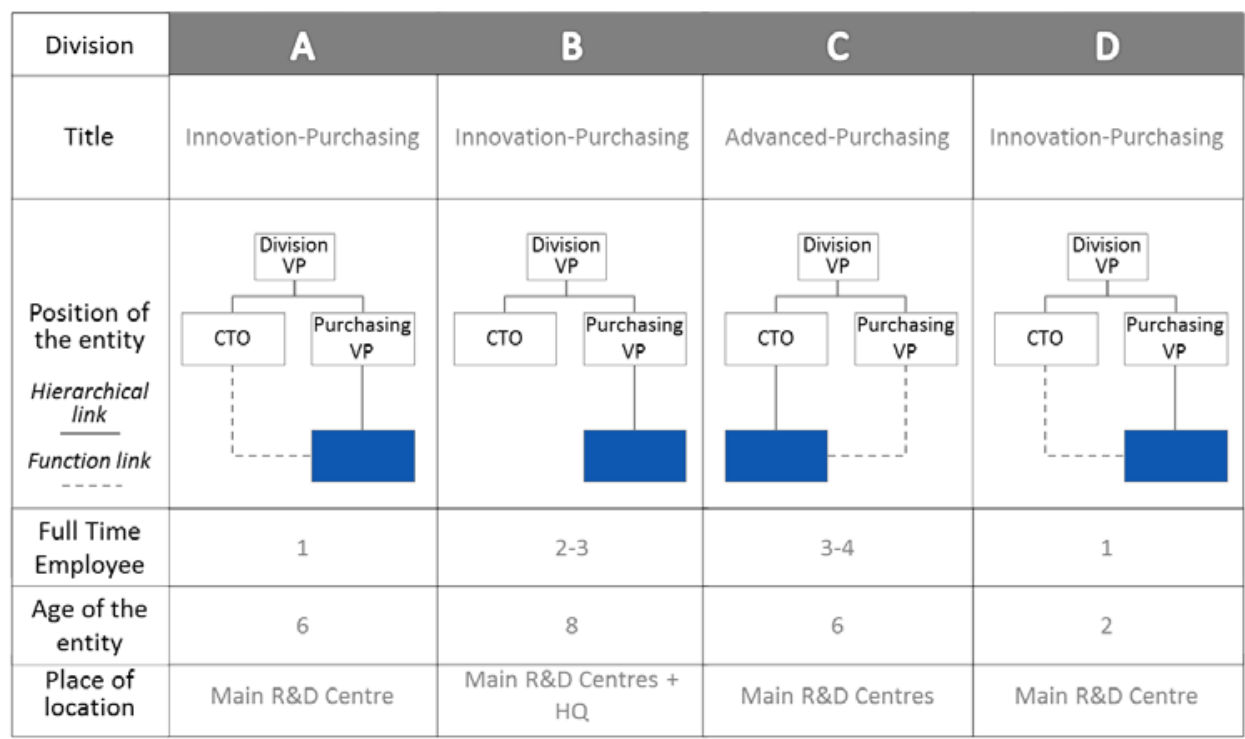

Table3: overview of the attributes of Innovation-Purchasing entities of AUTO group

In Division A, one Purchasing manager is awarded the title of "Innovation-Purchasing manager", who is dedicated full-time. The position has existed for more than four years. Initially inspired by Division B’s Innovation-Purchasing entity, it has the same assignments: (a) fuel and generate innovation ideas from suppliers, (b) strengthen interfaces with external innovation partners through contracts preparation and negotiation, and (c) follow-up and support innovation projects. This entity also shares with Division B's entity its key performance indicators, which are the number of collected innovative ideas, the number of realized events with external organizations and the number of signed contracts. The current Innovation-Purchasing, a senior Purchasing manager, took the position 6 months before the beginning of data collection. She hierarchically reports to the Strategy and Purchasing Director (under the Purchasing Vice-President) and has a functional link with the innovation 
director. She is based in the main R\&D centre of Division A and comes to the international headquarters once a week to "meet the Purchasers".

Division B has the oldest Innovation-Purchasing entity, created as a dedicated Direction 7 years before data collection. Since then, its missions and key performance indicators have not changed. This entity is the only one centralizing the management of Non-Disclosure agreements regarding innovation, for its entire division. Its founding director is hierarchically linked to Division B's Purchasing Vice-President. He is based half-time in the main R\&D centre of Division B and in international headquarters. His team is regularly composed of two Innovation-Purchasing managers: one is based in the same $R \& D$ centre (the job was carried out half-time by one of the authors), and the other in the second main $R \& D$ centre of the division. Since its creation, official guidelines of the roles, processes and tools of InnovationPurchasing are part of Division B quality system. They are regularly actualized and validated by Purchasing and R\&D senior managers.

In Division C, the Advanced-Purchasing function was created more than four years before data collection. Its main mission is to (a) consult and manage suppliers, (b) compare costs, (c) ensure quality, (d) meet delivery deadlines, and (e) ensure gate reviews are supported within the framework of the innovation program management system. This function is hierarchically linked to the Innovation Director, and reports to the Purchasing Vice-President. The manager of the entity and one of its three Advanced Buyers are based in the main R\&D centre; the other Program Innovation Buyers are based in two other R\&D centres. They are involved in innovation projects once the project's objectives are defined and the first gate is passed.

In Division D, Innovation-Purchasing is a recent function held for around two years by one dedicated purchaser reporting to the Purchasing Vice-President, with a functional link with the Innovation Director. It has the same mission as Division A's and Division B's. The 
Innovation-Purchaser is based in Division B's main R\&D centre, in the same open space as Innovation Project Managers. Its key performance indicators are (a) the number and origins of innovative ideas, (b) the ideas selected by Innovation, and (c) their status. Its role in the gate review is to conduct a synthesis of the monthly review and transfer it to other Purchasing functions.

\subsection{Results}

The described functions display several recurrences that define the role of the InnovationPurchasing function at AUTO group and provide an extension of the earlier studies on EPI. In the same way as the former studies reviewing case studies of collaborative NPD projects at one firm and/or the contribution of Purchasing to NPD project, this study was conducted by looking at the activities and tools of the Purchasing function dedicated to Innovation. Based on a reference framework, our study confirmed existing activities and revealed new activities related to fuzzy-front-end of innovation and other new ones that connect $R \& D$ and Purchasing, at strategic and operational levels. In this section, we detail the newly identified activities (represented in bold characters in Table 4) performed by Innovation-Purchasing based on the reference framework.

\begin{tabular}{|c|c|c|c|}
\hline Area & $\begin{array}{l}\text { Levels of } \\
\text { management }\end{array}$ & $\begin{array}{l}\text { Activities performed by Innovation- } \\
\text { Purchasing for managing supplier } \\
\text { involvement in innovation }\end{array}$ & $\begin{array}{l}\text { Activities performed by client-firm for } \\
\text { managing supplier involvement in } \\
\text { NPD(Van Echtelt et al., 2008) }\end{array}$ \\
\hline \multirow{5}{*}{$\begin{array}{l}\text { Strategic } \\
\text { management }\end{array}$} & \multirow{4}{*}{$\begin{array}{l}\text { Client's } \\
\text { innovation } \\
\text { activities }\end{array}$} & $\begin{array}{l}\text { Suggesting new technologies, } \\
\text { components, suppliers }\end{array}$ & \multirow{4}{*}{ None } \\
\hline & & $\begin{array}{l}\text { Formulating and communicating } \\
\text { guidelines / procedures for supplier } \\
\text { involvement }\end{array}$ & \\
\hline & & $\begin{array}{l}\text { Ensuring a continuous flow of new } \\
\text { technologies, components and suppliers }\end{array}$ & \\
\hline & & Linking R\&D and Purchasing strategies & \\
\hline & $\begin{array}{l}\text { Client's } \\
\text { development }\end{array}$ & Determining in-outsourcing technologies & $\begin{array}{l}\text { Determining in-outsourcing technologies } \\
\text { and NPD activities }\end{array}$ \\
\hline
\end{tabular}




\begin{tabular}{|c|c|c|c|}
\hline & activities & $\begin{array}{l}\text { Formulating and communicating guidelines } \\
\text { / procedures for supplier involvement }\end{array}$ & $\begin{array}{l}\text { Formulating and communicating } \\
\text { guidelines / procedures for supplier } \\
\text { involvement }\end{array}$ \\
\hline & \multirow{6}{*}{$\begin{array}{l}\text { Supplier } \\
\text { interface }\end{array}$} & None & $\begin{array}{l}\text { Monitoring supplier markets and current } \\
\text { suppliers for relevant developments }\end{array}$ \\
\hline & & $\begin{array}{l}\text { Pre-selecting suppliers for future } \\
\text { contribution to innovation }\end{array}$ & $\begin{array}{l}\text { Pre-selecting suppliers for future } \\
\text { involvement in NPD }\end{array}$ \\
\hline & & $\begin{array}{l}\text { Motivating panel suppliers to contribute } \\
\text { to client's innovation }\end{array}$ & None \\
\hline & & None & $\begin{array}{l}\text { Exploiting existing supplier skills and } \\
\text { capabilities }\end{array}$ \\
\hline & & $\begin{array}{l}\text { Motivating suppliers to develop specific } \\
\text { knowledge or products }\end{array}$ & $\begin{array}{l}\text { Motivating suppliers to develop specific } \\
\text { knowledge or products }\end{array}$ \\
\hline & & None & $\begin{array}{l}\text { Periodically evaluating guidelines and } \\
\text { supplier base performance }\end{array}$ \\
\hline \multirow{12}{*}{$\begin{array}{l}\text { Operational } \\
\text { project } \\
\text { management }\end{array}$} & Product & $\begin{array}{l}\text { Suggesting alternative technologies, } \\
\text { components, suppliers }\end{array}$ & $\begin{array}{l}\text { Suggesting alternative technologies, } \\
\text { components, suppliers }\end{array}$ \\
\hline & \multirow{9}{*}{ Project } & $\begin{array}{l}\text { Conducting project specific make- } \\
\text { develop-or-buy analysis on potential } \\
\text { solutions }\end{array}$ & $\begin{array}{l}\text { Determining project specific develop-or- } \\
\text { buy solutions }\end{array}$ \\
\hline & & $\begin{array}{l}\text { Ensuring the integrity of communication } \\
\text { interactions with potential suppliers }\end{array}$ & None \\
\hline & & $\begin{array}{l}\text { Selecting suppliers for involvement in } \\
\text { project }\end{array}$ & $\begin{array}{l}\text { Selecting suppliers for involvement in } \\
\text { project }\end{array}$ \\
\hline & & $\begin{array}{l}\text { Determining extent and moment of supplier } \\
\text { involvement }\end{array}$ & $\begin{array}{l}\text { Determining extent and moment of } \\
\text { supplier involvement }\end{array}$ \\
\hline & & $\begin{array}{l}\text { Formulating and monitoring purchasing } \\
\text { topics in project management }\end{array}$ & None \\
\hline & & $\begin{array}{l}\text { Challenging operational targets and work- } \\
\text { package }\end{array}$ & $\begin{array}{l}\text { Determining operational targets and } \\
\text { work-package }\end{array}$ \\
\hline & & None & $\begin{array}{l}\text { Designing communication interface with } \\
\text { suppliers }\end{array}$ \\
\hline & & Supplier-related problem solving & $\begin{array}{l}\text { Coordinating development activities with } \\
\text { suppliers }\end{array}$ \\
\hline & & $\begin{array}{l}\text { Accompanying suppliers for } \\
\text { administrative requests }\end{array}$ & None \\
\hline & Product & None & Evaluating part designs \\
\hline & $\begin{array}{l}\text { Supplier } \\
\text { interface }\end{array}$ & None & $\begin{array}{l}\text { Evaluating / feeding back supplier } \\
\text { performance }\end{array}$ \\
\hline
\end{tabular}

BOLD - newly observed activities in our sample compared to classical ESI activities

Table 4: Management processes for managing EPI ${ }^{2}$ vs EPI

\section{New activities in the area of Strategic management}

In the strategic management area, we were first led to distinguish one new level of management regarding the initial frameworks: we added the level of Innovation management to the levels of Development management and Supplier interface management. We defined Innovation management as the set of managerial processes and routines performed by Innovation-Purchasing that focuses on bringing innovation opportunities from outside the 
firm, and on establishing policies and guidelines for (1) supplier involvement in innovation activities, (2) ensuring a continuous flow of innovation opportunities, and (3) aligning the strategic management of the Purchasing department and of the R\&D department.

The first set of activities, "Suggesting new technologies, components and suppliers", is every entity’s task:

"We are looking for a continuous generation of ideas. We do that through the innovation days, technical meetings with suppliers, out of the box events for dedicated topics, calls for innovation by commodity, visits of tradeshows/fairs, and the possibilities to submit a suggestion in the AUTO group website... The objective is to provide ideas following our innovation tracks but also to go beyond. We can attend a fair which has nothing to do with the automotive industry, like furniture for example. We want to bring new suppliers to the AUTO group... It can provide us added value, even if it is still on the market" - Division A Innovation-Purchasing Manager

The second activity, "Formulating and communicating guidelines / procedures for supplier involvement", is carried out only by Division B. In this Division, where the Innovation-Purchasing function is the oldest entity, its procedures are described, and regularly updated, in the division quality system. These procedures are aligned together with the stage-gate procedures for innovation projects and with the sourcing procedures conducted by life-cycle Purchasing. It is completed by three generic contracts that guide suppliers' contractual involvement in innovation projects: non-disclosure agreement, engineering study contracts and co-innovation contracts.

The third set of activities, "Ensuring a continuous flow of new technologies, components and suppliers", consists in organizing the external flow of ideas and motivating other internal actors, specifically from R\&D, to continuously look for and suggest technologies, 
components and suppliers for future innovation - whatever their origins, whether the firms belong to the current supplier's base, or not. A key activity proves to be the selection of innovation opportunities, led by Innovation-Purchasing with R\&D actors. In Division A and $\mathrm{D}$, this selection is made through regular "fuelling committees" with R\&D, Marketing and Purchasing Directors. In Division B, this selection is first made with R\&D actors through successive exchanges between them and the potential supplier; later, the Directors check innovation opportunities when it is time to present them and include them in the innovation project system.

"Once we have identified an interesting idea, we are looking for the relevant technical specialist. If he/she is interested, we organize a meeting with them and we invite other people. With that process, we get the maximum payback with the minimum investment. The higher in the organization you present ideas, the less chance they have to be successful. So, you have to present ideas first at operation level” - Division B Innovation-Purchasing Director

The fourth set of activities, “Linking R\&D and Purchasing strategies”, turns out to be an emerging activity that requires creating new communication channels between the Purchasing and Research \& Development departments:

"There is one mid-long-term plan for Innovation, and another one for Purchasing. The question is how to get them to match when they don't know each other... I created this when I arrived because, naturally, Purchasing and R\&D didn't want to share information. I created my own shared place on the R\&D intranet, where I present what I do: non-disclosure agreements, co-development contracts, fairs, etc.. I also organized meeting between the two entities. $R \& D$ and Marketing presented their 
strategic roadmaps to Purchasing. Now the commodity purchasers are aware of Innovation tracks” - Innovation-Purchasing Manager of Division A

"Linking Purchasing and $R \& D$ through sharing the $R \& D$ roadmap from Innovation Director to Purchasing Directors is a new practice for Division B. We have tested it since the beginning of this year on 2 commodities, with a common selection of panel suppliers who could bring innovations” - Innovation-Purchasing Director of Division B

“Until now, R\&D didn't want to communicate to Purchasing the projects they were working on. After two years of negotiation, I managed to get them to present them, thanks to the Innovation Director. Now, at every innovation committee, I receive the projects' presentations. I synthesize them and transmit to all concerned commodity purchasers to what extent they will be impacted: description of the project, concept drawing, status, involved suppliers, planning, etc. - Innovation-Purchaser of Division $\mathrm{D}$

It also turns out these activities rely, on a daily basis, upon the physical presence of Innovation-Purchasing entities, together with people from the main R\&D centres.

The activity called “Motivating panel suppliers to contribute to clients' innovation” was the last identified in the strategic management of supplier interface: Innovation-Purchasing entities are not only contributing to select panel suppliers for future projects but also motivating them to contribute to clients' innovation. This motivation is achieved through three types of activities: rewarding innovative suppliers and organizing innovation-dedicated events for the selected suppliers. It is complementary to the activity of motivating suppliers to develop specific knowledge or products, which consists in AUTO group informing them on the division's innovation tracks and asking them to suggest innovations: 
"Based on the innovation tracks of Division A, with Purchasing we added 2 other tracks: process efficiency and sustainability. And, we present that in the supplier strategic meeting, which is the yearly meeting, in the presence of the Commodity Purchasing Director, when we exchanged results and perspectives with the supplier. I gave them a definition of innovation and told them how important it is to get an added value, not a super product”. Innovation-Purchasing Manager of Division A

The verbatim also revealed that the impact of this kind of activities could be minimized when they were not aligned with life-cycle Purchasing activities:

“We presented our investigation tracks to our suppliers during strategic committees.

But it is limited. Our suppliers told us that, after being treated roughly for 1 to 2 hours, we asked them for 10' to present us the innovative ideas. I have done it but I didn't get good results.” - Advanced-Purchasing Manager of Division C

Regarding the activities linked to the Development management of the client-firm, our data could not confirm the two sets.

\section{New activities in the Operational management area}

In operational project management activities, our main findings are at the level of project management. First, we enriched the activity initially described as "Determining project specific develop-or-buy solutions" and named it, “Conducting project specific makedevelop-or-buy analysis on potential solutions”: at the very first stage of a supplier's involvement in an innovation project, Innovation-Purchasing conducted an entire makedevelop-or-buy analysis. This was possible thanks to the precision of the technical and marketing expectations of the project, and of the expectations regarding potential suppliers. It 
is the first step that led us to the next set of activities regarding the determination of the extent and the time when the supplier gets involved in the project.

"When, during an innovation project, there is a potential co-development with an external partner, Innovation-Purchasing organizes a meeting with the project manager, related experts, marketing manager and sometimes commodity purchaser. The objective is to determine what the expectations of Division B versus an external partner should be: what will be the targeted innovation? What will be the related volume? With what timing? On which type of vehicle? What would be the ideal value sharing scheme, intellectual property and business?... This process can lead to the decision of making the project internally, rather than outsourcing it or to buying a product on-shelf and at the same time changing technical solutions. It can also lead to launch a first study or a co-development. From the specifications determined during this meeting, the negotiation with external partners can start." - InnovationPurchasing Manager of Division B

Second, we identified another set of activities performed by Innovation-Purchasing that allowed their firm to safeguard its interests regarding the innovation project: "Ensuring integrity of communication interactions with potential suppliers". Confidentiality agreements and confidentiality briefing of $R \& D$ actors, and sometimes of life-cycle Purchasing actors, in the presence of external organization, is performed by InnovationPurchasing. Indeed, when exchanges are organized with external organizations on innovation-related topics, and when Delcar has to disclose confidential information, it must be done under a confidentiality agreement. At the very least, internal staff must be briefed to remind them that confidential information cannot be disclosed, or then again - if a confidentiality agreement has been signed - inform them of which topic is being dealt with, 
and ask them not to disclose confidential information about any other subject. The internal staff is sometimes reminded of these principles in the presence of the external organization, but most of the time this is done before the meeting takes place.This activity consists in simultaneously minimizing information disclosures and contractual lock-in since fuzzy-frontend:

“Everyone can go outside to scout for ideas but no one can externally disclose confidential information. If someone wants to go further with a supplier, he comes to see us. We check with him whether there is a need for a non-disclosure agreement or not. If so, we manage it. We have to be careful, a non-disclosure agreement is a mutual agreement; there is reciprocity. We put it in place only if we need to disclose information.” Division B Innovation-Purchasing Director

Third, Innovation-Purchasing is also "Formulating and monitoring purchasing topics in project management” for NPD and innovation projects. These activities first appear when determining the extent of the supplier's involvement in a project. Later, these activities are twofold. On one hand, they are performed through the involvement of Innovation-Purchasing in the innovation project management stage-gate process. Innovation-Purchasing entities of Division A and Division B participate to every monthly innovation committee; they have a veto power over the validation of every stage when external partners (supplier or research consortium) are involved.

"I contribute to the innovation committee with $R \& D$. There is a stage-gate review when Purchasing is involved and I have a veto-right. I participate in all innovation committees. At each gate, there is a point dedicated to Purchasing: on the codevelopment contract or on price. In the responsibility matrix, Purchasing is systematically there.” Division A Innovation-Purchasing Manager 
Advanced-Purchasing entity of Division $\mathrm{D}$ is in charge of the deliverables regarding the evaluation of future external costs:

"At the first stage, we always define a bill of purchase, where we give an early costestimate. At the second stage, $25 \%$ of the value of the parts is estimated. At the third stage, it goes to $75 \%$. At the fourth stage, we must reach $100 \%$, thanks to the supplier's estimate that is compatible to the life-series of the product. And in between gates, nomenclature evolves.” Division D Advanced-Purchasing Manager

Our studies also revealed two other activities of Innovation-Purchasing at project management level. The "Supplier-related problem solving" set restrains the set of activities of the reference framework as regards the coordination of development activities with suppliers. We find this coordination during the project is mainly related to supplier-related problem solving, such as payment or delayed negotiation, as the coordination tasks are assumed by R\&D actors and more focused on the project itself.

One last identified set of activities could also be at the level of supplier interface management, as it is not always related to a dedicated project: “Accompanying suppliers for administrative requests”. In Division A, the supplier can be accompanied to get official agreements in order for them to give to Auto group the possibility to obtain subsidies linked to innovation projects. In Division B and Division D, the new supplier is helped in his journey to become, administratively, a panel supplier; Division B procedures specify how to integrate it to Purchasing sourcing procedures. 


\section{Discussion}

This paper contributes to the awareness of different "shades" of Purchasing involvement in an Open Innovation context, that goes beyond New Product Development. By addressing our research question we can highlight three main theoretical findings of our study concerning the specific role of the actors who are in charge of the Innovation-Purchasing function: their role in the Open Innovation capacity of their firm, in its ambidexterity and in its relational capabilities with its innovation partners. After discussing the specificity of this new function, we successfully present and discuss them.

Our study is consistent with the earlier literature that shows the possible distinction in the purchasing departments between entities that are in charge of "life-cycle" sourcing, and of "advanced" sourcing, and of "fuzzy-front-end" sourcing, the latter entity being also in charge of managing the link between $R \& D$ and the other entities. It provides an early description of this distinction that was only punctually detected. We had the opportunity to conduct this observation with four departments in the same firm, which are long-term established and are actively involved in the innovation processes of their divisions. Yet, we can distinguish on one hand the advanced sourcing function, primarily dedicated to established New Product Development project, and on the other the fuzzy-front-end innovation sourcing function, which is mainly dedicated to innovation in a wider sense, and to the fuzzy-front-end of innovation, at stages where specifications or needs are not yet defined.

Besides, this Purchasing function can also be distinguished from other functions, mainly linked to R\&D, Marketing and Strategy, which are in charge of Innovation scouting, technology and market intelligence as well as other Open Innovation activities. This distinction is based on Innovation-Purchasing's multiple roles: upstream, the scouting contributes to the firm's strategy definition by conciliating Purchasing and R\&D stakes; 
downstream, it contributes to the acquisition and management of external ideas, technologies and suppliers. That last contribution is very specific to Purchasing as it embraces the future exploitation of targeted co-innovation: this exploitation is anticipated externally through contract design; and internally through the inclusion of life-cycle purchasing processes. These prerogatives make it a unique role, where its double title reflects its full link to both Innovation and Purchasing functions.

\subsection{Innovation-Purchasing and Open Innovation}

First, our study shows the role of the Innovation-Purchasing function in the Open Innovation of their firm. Innovation-Purchasing manages the relationships of external entities involved in the Innovation process: it actively participates to their scouting and selection but also at an operational level, by defining the contract and organizing the follow-up. These actions represent what makes a firm's Absorptive Capacity, i.e. its capacity to “recognize the value of new, external information, assimilate it, and apply it to commercial ends" (Cohen \& Levinthal, 1990, p. 128).

Further, this function ensures continuity from the very first phase of their involvement in fuzzy-front-end to the transfer to the development phase that leads to commercialization. First, Innovation-Purchasing introduces, validates and follows up new technologies, components, and suppliers. Later, through the Make-Share-or-Buy process, and the contract negotiation where required, the long term involvement and motivation of internal and external actors is secured by fixing their respective expectations, rights and obligations. Now, as these roles ensure the firm's absorptive capacity, which is a pillar for successful Open Innovation (West \& Bogers, 2014), in line with (Rehm et al., 2015) we can propose that 
Proposition 1a: $\mathrm{EPI}^{2}$ positively impacts the firm’s Open Innovation capability.

More precisely, in the fuzzy-front-end of innovation, Innovation-Purchasing proves to be in charge of innovation scouting dedicated to existing and future suppliers, on existing or new technologies. External knowledge sources extend from traditional supplier to start-up and research laboratories. Its scouting area comprises the firm's existing supplier base, traditionally managed by life-cycle Purchasing, and extends to new knowledge sources such as start-up and research laboratories, which is traditionally managed by Research and Development. The specificity of its position, in-between both functions, enables InnovationPurchasing to enhance the realm of its scouting.

Furthermore, thanks to its knowledge of R\&D and Purchasing strategies and stakes, Innovation-Purchasing gets a wider vision of a firm's current needs for new ideas, technologies, components, and suppliers, relatively to other functions. As these functions are involved later and together through the selection process, they can contribute to enrich external knowledge by providing their own knowledge and views. Thus, based on a wider initial basis of external ideas and internal needs, new knowledge combinations are even increased. So we can propose that

Proposition 1b: $\mathrm{EPI}^{2}$ positively impacts the number of external ideas in fuzzy-front-end Open Innovation

This selection process is carried out via a Make-Share-or-Buy analysis conducted by Innovation-Purchasing before any contractual involvement of an external organization to an innovation project, the innovative idea, technology or component, being scouted, or not, by Innovation-Purchasing. Following this process, other functions than R\&D are involved in Innovation-Purchasing in order to decide whether external ideas might be internalized (Make), externalized (Buy), jointly developed (Share), or abandoned (Lazzarotti \& Manzini, 
2009; Le Dain, Calvi, \& Cheriti, 2011). If this process can reduce the number of external ideas that are acquired by their firm, it also opens up the realm of what is to be acquired. This leads to other sources of contractual governance for Open Innovation partnerships. When Open Innovation is focused on stakes related to intellectual property sharing, introducing the question of "Making" in the selection process leads to additionally consider the stakes relative to the realization of innovation. And when Purchasing is focused on how to best "Buy" and minimize risks, introducing the question of "Sharing" leads to introducing stakes related to design and specifically to uncertainty. To that end:

Proposition1c: $\mathrm{EPI}^{2}$ increases the variety of contractual governance for managing Open Innovation activities

\subsection{Innovation-Purchasing and ambidexterity}

Second, our study underlines how Innovation-Purchasing connects R\&D with Purchasing, at strategic and operational levels. At strategic level, they link strategic sourcing and innovation strategy (Luzzini et al., 2015) through (1) sharing innovation strategies among the Purchasing community and (2) building-up guidelines for managing external resources for their firm's innovation. At operational level, they represent the Purchasing community within the innovation project process and during the selection process of external firms involved in the firm's innovation projects. Purchasing and R\&D are two functions in firms that can be considered as two representatives of what March describes as, respectively, exploitative and explorative functions (March, 1991). These types of functions traditionally work with different tools, people and goals, which can prove hardly compatible. The congruence of such functions is key for the firm's competitive advantage, as it materializes the firm's 
organizational ambidexterity (Jurksiene \& Pundziene, 2016). Innovation-Purchasing ensures, at strategic and operational level, such congruence between Purchasing and R\&D, internally. Thus, the Innovation-Purchasing function offers a solution to March's dilemma in terms of organisation.

It is also solves this dilemma in the dynamic of collaborative innovation, which is presented as the Open Innovation paradox: the creation of innovations requires openness whereas the commercialization of innovations requires protection (Laursen \& Salter, 2014). In the acquisition process of external knowledge, its future exploitation is taken into account, above the project boundaries and above the issue of intellectual property: the future potential clientsupplier relationship is considered early on, modulo the uncertainties linked to the project. For that purpose:

Proposition 2: $\mathrm{EPI}^{2}$ positively impacts the firm's ambidexterity

\subsection{Innovation-Purchasing and relational capability}

Last, in NPD, the impact of the consistency of the client-firm's different functions relatively to the supplier-firm is still questioned. Recently, voluntary inconsistency was revealed to provide a positive impact on supplier involvement. In this case, this inconsistency is based on a "good cop-bad cop" strategy as regards external resources, where Purchasing is the bad cop and R\&D the good cop (Brattström \& Richtnér, 2013). In case of problems, the functions of the client-firm present a different attitude towards the supplier-firm in order to solve the problem without spoiling the relationship. This is possible thanks to an internal alignment between the two functions within the client-firm. The literature reveals that such alignment is only possible through physical proximity, which allows formal and informal information 
sharing (Gonzalez-Zapatero et al., 2016), which is the case of the four entities described in our study. Still, $\mathrm{EPI}^{2}$ contributes not only to the innovation capacity of their firm but also to its relational capability - i.e. the ability of a company to evaluate, select and mobilize external capacity (Lorenzoni \& Lipparini, 1999) - this capability being complemented by an intra-firm coordination capability in order to manage the links and interactions between the firm’s different activities (Roberts, Galluch, Dinger, \& Grover, 2012). Our findings indicate that in fuzzy-front-end, this capability is based on a Purchasing function that acts as facilitator, internally and externally. At buying firm level, it integrates the ability to manage alliances, (“alliance capability” or “alliance management capability”) (Kale, Dyer, \& Singh, 2001). It should refer sometimes to what (Phillips et al., 2006) call a "strategic dalliance": this is a short-term collaboration for a one-shot project link to some opportunistic need for a technical solution. Besides, these $\mathrm{EPI}^{2}$ capabilities are activated at strategic and operational levels:

Proposition 3: $\mathrm{EPI}^{2}$ positively impacts its firm’s relational capability

\section{Conclusion}

The research objective of this paper was to describe the role of a new actor in Open Innovation: the professional buyer involved early on in innovation activities, which differs from the more traditional role of buyer, early involved in specific NPD projects. To that end, we had the opportunity to conduct an in-depth case study realized in a multinational multidivisional firm, where such new actor has been implemented for more than nine years and disseminated across all its four divisions. We studied this actor's different roles, using an EPI framework; we discovered new activities that distinguish this role as a fully-fledged one. 
This paper contributes empirically to the emerging research on EPI, especially the stream in that literature that focuses on the particular challenge of capturing innovation from the supplier market $\left(\mathrm{EPI}^{2}\right)$, by giving an early description of its role and specificities in the fuzzyfront-end of innovation relatively to other better-known Purchasing functions involved in New Product Development. This paper also contributes to the Open Innovation literature by describing a function that contributes to solving the challenges of integrating exploration and exploitation: at firm level, such a function contributes to the firm's ambidexterity and, at project level, it contributes to solving the paradox of openness, which widens its exploration capacity but threatens its future exploitation capacity. Thus, our study constructively responds to the recent call for studying new functions involved in Open Innovation. It demonstrates the value of responding to such a call by the complexity of the tasks and the multiplicity of actors Innovation-Purchasing is dealing with.

From a managerial point of view this seems to be a relevant issue, due to the number of firms communicating on the creation of the Innovation-Purchasing function, at least in the European context. Through the description of the roles and activities of InnovationPurchasing, we contribute to define a job description for managers that are looking to create or develop such a position in their firms. We also contribute to establishing a distinction between "project purchaser" and "innovation purchaser", the first being specifically dedicated to defined projects, where there is a specified need for sourcing a specific external resource; and the second being more largely dedicated to the Open innovation context, when there is a need for external resources to nurture the focal firm's innovation capability. Innovation-Purchasing involvement begins at the fuzzy-front-end of innovation and implies being able to build-up the relationship with the external partner, as early on as these early stages. 
In a wider context, it proves to be an interesting way of addressing Open Innovation challenges when they are based on, or are targeting, client-supplier relationships: through the positive involvement of a dedicated Purchasing function. Furthermore, this distinction can help $R \& D$ and Innovation managers to clarify what they can expect from the different Purchasing entities, and help Human Resource managers learn how to recruit and follow-up the Purchasing actors dedicated to innovation. Last but not least, this work can also provide the managers of supplying firms that contribute to their client's innovation projects with a better knowledge of what they can obtain from the Purchasing entities dedicated to Innovation.

Our in-depth case study presents the traditional limitations associated with its methodology. More specifically, as the study was conducted in one firm in the automotive industry, an industry where supplier's involvement and Purchasing's involvement in innovation is more topical and studied more often than in other industries (T. E. Johnsen, 2009), the results could be of limited use in other industries, since they are less mature on the subject. Then, while case findings based on unique but in-depth case studies are useful for understanding emerging and rare cases (Yin, 2009) and theory building (Meredith, 1998), our approach was explorative and the results need further investigation with other cases and methodologies, if they are to be generalized. While we did distinguish new activities in $\mathrm{EPI}^{2}$ as regards EPI, we were not able to capture all the former EPI activities: the question remains open as to what extent $\mathrm{EPI}^{2}$ differs from EPI. These limitations open avenues for further research before generalizing major managerial implications. However, our findings contribute to defining the boundaries of this new function and highlight the competences required to fully perform this emerging function. 


\section{References}

Ben Mahmoud-Jouini, S., \& Charue-Duboc, F. (2014). Establishing relationships with suppliers with distant knowledge to target discontinuous innovation. In Academy of Management Proceedings.

Blome, C., Schoenherr, T., \& Kaesser, M. (2013). Ambidextrous Governance in Supply Chains: The Impact on Innovation and Cost Performance. Journal of Supply Chain Management, 49(4), 59-80.

Brattström, A., \& Richtnér, A. (2013). Good Cop-Bad Cop: Trust, Control, and the Lure of Integration. Journal of Product Innovation Management, 31(3), 584-598.

Brem, A., \& Tidd, J. (2012). Perspectives on Supplier Innovation: Theories, Concepts and Empirical Insights on Open Innovation and the Integration of Suppliers (Vol. 18). World Scientific.

Brentani, U., \& Reid, S. E. (2012). The Fuzzy Front-End of Discontinuous Innovation: Insights for Research and Management. Journal of Product Innovation Management, 29(1), 70-87.

Chesbrough, H. (2003). Open Innovation: The New Imperative for Creating and Profiting from Technology. Boston: Harvard Business Press.

Chesbrough, H., \& Euchner, J. (2011). The Evolution of Open Innovation: An Interview with Henry Chesbrough. Research-Technology Management, 54(5), 13-18.

Chesbrough, H., Vanhaverbeke, W., \& West, J. (2014). New frontiers in open innovation. Oxford University Press. Retrieved from

Cohen, W. M., \& Levinthal, D. A. (1990). Absorptive Capacity: A New Perspective on Learning and Innovation. Administrative Science Quarterly, 35(1), 128-152. 
Cousins, P. D., Lawson, B., Squire, B., Cousins, P. D., Lawson, B., \& Squire, B. (2006). An empirical taxonomy of purchasing functions. International Journal of Operations \& Production Management, 26(7), 775-794.

Dahlander, L., \& Gann, D. M. (2010). How open is innovation? Research Policy, 39(6), 699709.

D’Antone, S., \& Santos, J. B. (2016). When purchasing professional services supports innovation. Industrial Marketing Management.

Dubois, A., \& Araujo, L. (2007). Case research in purchasing and supply management: Opportunities and challenges. Journal of Purchasing and Supply Management, 13(3), $170-181$.

Eslami, M. H., \& Lakemond, N. (2015). Internal integration in complex collaborative product development projects. International Journal of Innovation Management, 20(1), 1650008.

Farmer, D. (1981). The role of procurement in new product development. International Journal of Physical Distribution \& Materials Management, 11(2/3), 46-54.

Gardet, E., \& Mothe, C. (2011). The dynamics of coordination in innovation networks. European Management Review, 8(4), 213-229.

Gassmann, O., \& Enkel, E. (2004). Towards a Theory of Open Innovation: Three Core Process Archetypes. In $R \& D$ management conference.

Gonzalez-Zapatero, C., Gonzalez-Benito, J., \& Lannelongue, G. (2016). Antecedents of functional integration during new product development: The purchasing-marketing link. Industrial Marketing Management, 52, 47-59.

Johnsen, T., Calvi, R., \& Phillips, W. (2011). Purchasing and supplier involvement in discontinuous innovation: A literature review. In 20th Annual IPSERA Conference. Maastricht. 
Johnsen, T. E. (2009). Supplier involvement in new product development and innovation: Taking stock and looking to the future. Journal of Purchasing and Supply Management, 15(3), 187-197.

Johnsen, T. E., \& Mikkelsen, O. (2015). Exploring the management of vertical innovation cooperation: how do supplier and client organize their relationship. In Preparing for new competitive challenges 24th annual IPSERA conference. Amsterdam, Holland: IPSERA.

Jurksiene, L., \& Pundziene, A. (2016). The relationship between dynamic capabilities and firm competitive advantage: The mediating role of organizational ambidexterity. European Business Review, 28(4), 431-448.

Kale, P., Dyer, J., \& Singh, H. (2001). Value creation and success in strategic alliances:: alliancing skills and the role of alliance structure and systems. European Management Journal, 19(5), 463-471.

Kang, K. H., \& Kang, J. (2009). How do firms source external knowledge for innovation? Analysing effects of different knowledge sourcing methods. International Journal of Innovation Management, 13(1), 1-17.

Lakemond, N., Echtelt, F., \& Wynstra, F. (2001). A configuration typology for involving purchasing specialists in product development. Journal of Supply Chain Management, 37(3), 11-20.

Laursen, K., \& Salter, A. J. (2014). The paradox of openness: Appropriability, external search and collaboration. Research Policy, 43(5), 867-878.

Lawson, B., \& Samson, D. (2001). Developing innovation capability in organisations: a dynamic capabilities approach. International Journal of Innovation Management, 5(3), 377-400. 
Lazzarotti, V., \& Manzini, R. (2009). Different modes of open innovation: a theoretical framework and an empirical study. International Journal of Innovation Management, 13(4), 615-636.

Le Dain, M., Calvi, R., \& Cheriti, S. (2011). Measuring supplier performance in collaborative design: proposition of a framework. $R \& D$ Management, 41(1), 61-79.

Lorenzoni, G., \& Lipparini, A. (1999). The leveraging of interfirm relationships as a distinctive organizational capability: a longitudinal study. Strategic Management Journal, 20(4), 317-338.

Luzzini, D., Amann, M., Caniato, F., Essig, M., \& Ronchi, S. (2015). The path of innovation: purchasing and supplier involvement into new product development. Industrial Marketing Management.

Luzzini, D., \& Ronchi, S. (2010). Organizing the purchasing department for innovation. Operations Management Research, 4(1-2), 14-27.

Maniak, R., \& Midler, C. (2008). Shifting from co-development to co-innovation. International Journal of Automotive Technology and Management, 8(4), 449-468.

March, J. G. (1991). Exploration and Exploitation in Organizational Learning. Organization Science, 2(1), 71-87.

Melander, L., \& Lakemond, N. (2014). Variation of purchasing's involvement: case studies of supplier collaborations in new product development. International Journal of Procurement Management, 7, 103-118.

Melander, L., \& Lakemond, N. (2015). Governance of supplier collaboration in technologically uncertain NPD projects. Industrial Marketing Management.

Meredith, J. (1998). Building operations management theory through case and field research. Journal of Operations Management, 16(4), 441-454. 
Miles, M. B., Huberman, A. M., \& Saldana, J. (2014). Qualitative data analysis: A methods sourcebook (3rd edition). Thousand Oaks, CA: Sage Publications.

Mortara, L., \& Minshall, T. (2011). How do large multinational companies implement open innovation? Technovation, 31, 586-597.

Olausson, D., Magnusson, T., \& Lakemond, N. (2009). Preserving the link between R\&D and manufacturing: Exploring challenges related to vertical integration and product/process newness. Journal of Purchasing and Supply Management, 15(2), 79_ 88.

Parmigiani, A., \& Mitchell, W. (2010). The hollow corporation revisited: Can governance mechanisms substitute for technical expertise in managing buyer-supplier relationships? European Management Review, 7(1), 46-70.

Petersen, K. J., Handfield, R. B., \& Ragatz, G. L. (2005). Supplier integration into new product development: coordinating product, process and supply chain design. Journal of Operations Management, 23(3-4), 371-388.

Phillips, W., Lamming, R., Bessant, J., \& Noke, H. (2006). Discontinuous innovation and supply relationships: strategic dalliances. R\&D Management, 36(4), 451-461.

Pulles, N. J., Veldman, J., \& Schiele, H. (2014). Identifying innovative suppliers in business networks: An empirical study. Industrial Marketing Management, 43(3), 409-418.

Rehm, M., Schupp, F., \& Matthyssens, P. (2015). Developing a capability-based framework for purchasing's contribution to open innovation. In Preparing for new competitive challenges 24th annual IPSERA conference. Amsterdam, Holland: IPSERA.

Roberts, N., Galluch, P. S., Dinger, M., \& Grover, V. (2012). Absorptive Capacity and Information Systems Research: Review, Synthesis, and Directions for Future Research. MIS Quarterly, 36(2), 625-A6. 
Schiele, H. (2006). How to distinguish innovative suppliers? Identifying innovative suppliers as new task for purchasing. Industrial Marketing Management, 35(8), 925-935.

Schiele, H. (2010). Early supplier integration: the dual role of purchasing in new product development. $R \& D$ Management, 40(2), 138-153.

Schiele, H. (2012). Accessing Supplier Innovation By Being Their Preferred Customer. Research Technology Management, 55(1), 44-50.

Servajean-Hilst, R. (2014). Open Innovation in the French Automotive Industry: the case of a purchasing function detecting external knowledge and triggering its absorption. In European Academy of Management 2014 Conference. Valencia, Spain.

Smals, R. G. M., \& Smits, A. A. J. (2012). Value for value-The dynamics of supplier value in collaborative new product development. Industrial Marketing Management, 41(1), 156-165.

Trent, R. J., \& Monczka, R. M. (1998). Purchasing and supply management: trends and changes throughout the 1990s. Journal of Supply Chain Management, 34(4), 2-11.

Van Echtelt, F. E. A., \& Wynstra, F. (2001). Managing supplier integration into product development: a literature review and conceptual model. The Future of Innovation Studies.

Van Echtelt, F. E. A., Wynstra, F., Van Weele, A. J., \& Duysters, G. (2008). Managing Supplier Involvement in New Product Development: A Multiple-Case Study. Journal of Product Innovation Management, 25(2), 180-201.

Vanhaverbeke, W., West, J., \& Chesbrough, H. W. (2014). Surfing the New Wave of Open Innovation Research. In New Frontiers in Open Innovation (Oxford University Press). Oxford, England. 
West, J., \& Bogers, M. (2014). Leveraging External Sources of Innovation: A Review of Research on Open Innovation. Journal of Product Innovation Management, 31(4), 814-831.

Wynstra, F., Axelsson, B., \& Weele, A. van. (2000). Driving and enabling factors for purchasing involvement in product development. European Journal of Purchasing \& Supply Management, 6(2), 129-141.

Wynstra, F., van Weele, A., \& Axelsson, B. (1999). Purchasing involvement in product development:: A framework. European Journal of Purchasing \& Supply Management, 5(3), 129-141.

Wynstra, F., Weggeman, M., \& Van Weele, A. (2003). Exploring purchasing integration in product development. Industrial Marketing Management, 32(1), 69-83.

Yin, R. K. (2009). Case Study Research: Design and Methods (4th ed.). Sage Publications. 